\title{
Chironomid Fauna of the Lakes from the Pechora River Basin (East of European part of Russian Arctic): Ecology and Reconstruction of Recent Ecological Changes in the Region ${ }^{1}$
}

\author{
L. B. Nazarova ${ }^{a, b, c, *}$, A. E. Self ${ }^{d}$, S. J. Brooks ${ }^{d}$, N. Solovieva ${ }^{e, f}$, L. S. Syrykh ${ }^{c, g}, * *$, and V. A. Dauvalter ${ }^{h}$ \\ ${ }^{a}$ Potsdam University, Institute of Earth and Environmental Science, Potsdam-Golm, 2514476 Germany \\ ${ }^{b}$ Alfred Wegener Institute, Helmholtz Centre for Polar and Marine Research, Research Unit Potsdam, Potsdam, 14473 Germany \\ ${ }^{c}$ Kazan Federal University, Kazan, 420008 Russia \\ ${ }^{d}$ The Natural History Museum, London, UK \\ ${ }^{e}$ Environmental Change Research Centre, University College London, London WC1H OAP, UK \\ ${ }^{f}$ Higher Colleges of Technology, Sharjah, UAE, PO BOX 7947 \\ ${ }^{g}$ Herzen State Pedagogical University of Russia, St. Petersburg, 191186 Russia \\ ${ }^{h}$ Institute of the North Industrial Ecology Problems KSC RAS Apatity, Akademgorodok, 184209 Russia \\ *e-mail: Nazarova_larisa@mail.ru \\ **e-mail: lyudmilalsd@gmail.com
}

Received October 19, 2016; in final form, January 25, 2017

\begin{abstract}
We investigated chironomid fauna of surface sediments and a short sediment core (Bol'shoy Kharbey Lake) from Pechora river basin, Northern Russia. Twenty three investigated lakes have thermokarst, glacial or floodplain origin and are characterised by low mineralization, mostly hydrocarbon-calcium type of water and low concentration of nutrients. Most of the lakes have circumneutral $\mathrm{pH}$ around $\leq 7$ and only two lakes are slightly more acidic with $\mathrm{pH} \leq 6$. Ninety six chironomid taxa were identified in the surface sediments. Distribution of chironomids in the studied region is driven by continentality, mean $\mathrm{T}_{\mathrm{July}}$ and $\mathrm{pH}$. Chironomid communities from the core of the $\mathrm{B}$. Kharbei Lake demonstrate the highest similarity with the fauna of the deeper lakes of the glacial origin. The glacial lakes have the highest indices of continentality and the lowest winter temperatures within the investigated data set. The chironomid fauna of the glacial lakes is composed of the profundal, oligotrophic and cold-stenotherm taxa. The fauna of the floodplain and thermokarst lakes is more closely related to $T_{\text {July }}$ and is composed of littoral and phytophilic taxa of meso - or eutrophic waters and moderate temperature conditions. The fauna of the acidic thermokarst lakes considerably differs from the other lakes. Chironomid communities here are represented by tolerant to acidification taxa, and by the typically littoral and shallow water acid-tolerant taxa that apparently also can tolerate acidification. Studied sediment record covers $c a$ last 200 years. The reconstructed $\mathrm{T}_{\text {July }}$ during the entire period remain slightly below the modern temperatures. From 1970 reconstructed $\mathrm{T}_{\text {July }}$ shows steady increase to the modern level. The reconstructed water depths (WDs) of the lake are higher than today till 1980. The highest WDs are reconstructed for $c a$ 1970. After that the WDs gradually decrease to the modern level. Changes of the WDs are most probably related to changes in the precipitation rate.
\end{abstract}

Keywords: river Pechora basin, lakes, chironomids, temperature, depth, continentality, Russian Arctic

DOI: $10.1134 /$ S1995425517040059

\section{INTRODUCTION}

Arctic regions are sensitive to global climate change and the arctic waters are excellent indicators of the global temperature rise on the planet. The, arctic lake communities are particularly vulnerable to intensive industrial development, which makes studies of Arctic lakes and their biota especially important (Frolova et al., 2014). Long-term studies of aquatic communities may reveal dynamics of aquatic ecosystem responses to global climate change. Knowledge of the

\footnotetext{
${ }^{1}$ The article is published in the original.
}

entire spectrum of life strategies of the most important indicator group of benthic communities, which include heterotrophic chironomids, is essential for assessment of the ecological state of surface waters and for exploration of natural successions under the influence of natural and anthropogenic factors (Zinchenko, 2011; Kondrateva et al., 2014).

Studies of the lakes from Canadian Arctic, Scandinavia and Fennoscandia showed that the changes in their ecosystems are largely linked to global warming during the last 150-200 years (Smol et al., 2005). However, there are only few recent studies which 


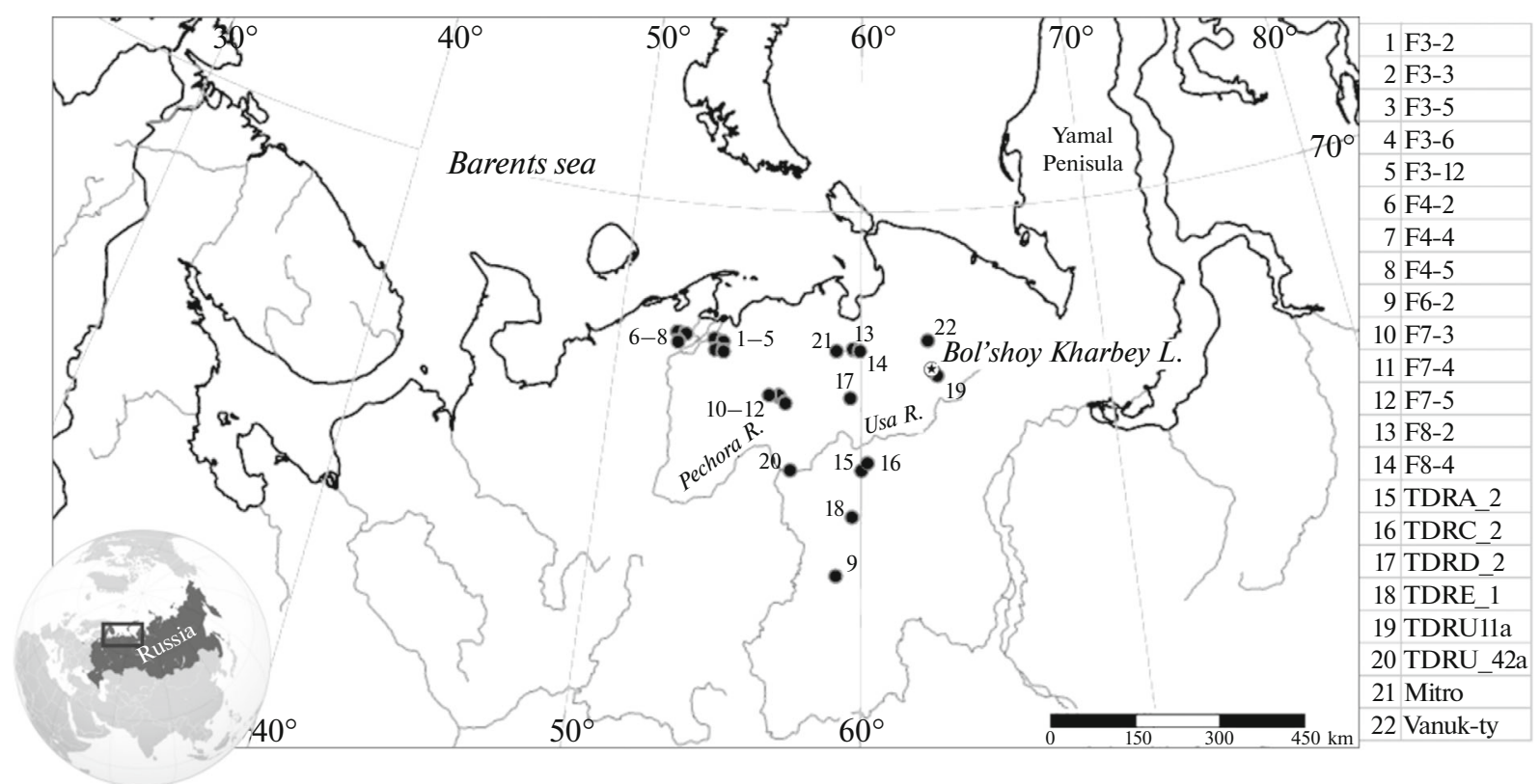

Fig. 1. Location of the investigated lakes.

investigated environmental changes in lakes from north-east of the European Russia (e.g. Solovieva et al., 2005, 2008; Nazarova et al., 2014; Palagushkina et al., 2014).

Chironomid larvae have many advantages as indicator organisms. Quick development and generations change, wide range of ecological adaptations and high sensitivity allows them rapidly respond to changing environment and make it possible to use them for evaluation and interpretation of environmental changes with a high degree of confidence (Brooks et al., 2007).

Chironomids are indicative of eutrophication, acidification, toxic pollution and other chemical and physical changes in the environment, and their headcapsules are well-preserved in sediments remains of their head capsules are widely used in paleoecology (Brooks and Birks, 2000; Massaferro and Brooks, 2002; Solovieva et al., 2005; Kienast et al., 2011).

Chironomid larvae are the most widespread and large group of zoobenthos of freshwaters (Nazarova et al., 2004; Epler, 2001). In the lakes of the eastern part of European Russian Arctic chironomids constitute up to $100 \%$ of the benthic communities (Kuzmina, 2001; Loskutova, 2002; Baturina et al., 2012; Kondrateva et al., 2014). At the same time, ecology of chironomids in the region still remains poorly studied and their application in palaeoclimatic studies is sporadic (Solovieva et al., 2005; Nazarova et al., 2014).

The aim of our study is to reconstruct recent palaeoecological conditions in the Bolshezemelskaya tundra using chironomid-based statistical models and data on the chironomid ecology in the region. In particular, the research focused on the following: (1) to study chironomid fauna of the lakes of Bolshezemel- skaya tundra and surrounding areas of the River Pechora basin; (2) to identify environmental factors affecting distribution of chironomid taxa in the region, and ecological features of the common chironomid taxa; (3) qualitative and quantitative reconstruction of the environmental conditions in the region during the last $c a 200$ years using chironomid sediment record from the Bol'shoi Kharbey Lake, Bolshezemelskaya tundra; (4) validation of the obtained quantitative reconstructions.

\section{MATERIALS AND METHODS}

Bol'shoi Kharbei Lake is located in the Pechora River basin (north-east of the European Russia, Fig. 1), which flows through Bolshezemelskaya, Malozemelskaya tundras to the south of the Arctic Circle through a coniferous taiga. The climate of the region is subarctic with long and cold winters, which lasts up to 8 months, and minimum temperatures going below $-50^{\circ} \mathrm{C}$ in January. Summer is short and cool. The warmest month is July (New et al., 2002) with the mean temperatures ranging from 8 to $12^{\circ} \mathrm{C}$ (Mukhin et al., 1964). The average annual precipitation varies from 370 to $395 \mathrm{~mm}$ (Mukhin et al., 1964).

22 lakes were sampled between 1998 and 2001 within the framework of interdisciplinary international European projects TUNDRA (TUNdra Degradation of Russian Arctic, 1998-2001, http://www.ib.komisc.ru/ en/international-scientific-cooperation/1088-tundra) and SPICE (Solovieva et al., 2002, 2005). Samples were selected along 4 transects crossing the major industrial centers of the region: Vorkuta (transect 1), Inta (transects 2 and 3) and Usinsk (transect 4). Some 
Table 1. Names of the lakes from Pechora basin, their main geographical and climatic parameters. $T_{\mathrm{July}}-\mathrm{mean}_{\mathrm{July}}$ air temperature, ${ }^{\circ} \mathrm{C}, \mathrm{T}_{\text {January }}$ - mean January air temperature, ${ }^{\circ} \mathrm{C}, \mathrm{CI}$-Gorczynski continentaliy index. Temperatures and $\mathrm{CI}$ are calculated by New et al., (2002). Lake origin: g-glaciar, f-floodplain, t-thermokast

\begin{tabular}{|c|c|c|c|c|c|c|c|c|c|}
\hline Lakes & Latitude, $\mathrm{N}$ & Longitude, E & $\begin{array}{l}\text { Altitude } \\
(\mathrm{m}, \text { asl) }\end{array}$ & $\begin{array}{c}\text { Water } \\
\text { depth, } \mathrm{m}\end{array}$ & S, ha & $\begin{array}{c}\mathrm{T} \\
\text { July, }{ }^{\circ} \mathrm{C}\end{array}$ & $\begin{array}{c}\mathrm{T} \\
\text { January, }{ }^{\circ} \mathrm{C}\end{array}$ & $\mathrm{CI}$ & Origin \\
\hline F3-2* & 67.93 & 54.03 & 13 & 4.3 & 11 & 13.3 & -19.1 & 39 & $\mathrm{f}$ \\
\hline F3-3* & 67.93 & 54.05 & 20 & 1.5 & 26 & 13.3 & -19.1 & 39 & $\mathrm{t}$ \\
\hline $\mathrm{F} 3-5^{*}$ & 67.92 & 54.03 & 17 & 3.3 & 12 & 13.3 & -19.1 & 39 & $\mathrm{f}$ \\
\hline F3-6* & 67.93 & 54.00 & 18 & 1.3 & 28 & 13.3 & -19.1 & 39 & $\mathrm{t}$ \\
\hline F3-12* & 67.95 & 53.93 & 13 & 2.8 & 13 & 13.3 & -19 & 39 & $\mathrm{f}$ \\
\hline $\mathrm{F} 4-2^{*}$ & 68.00 & 52.38 & 4.8 & 6 & 40 & 12.9 & -18.3 & 37 & $\mathrm{f}$ \\
\hline $\mathrm{F} 4-4^{*}$ & 68.00 & 52.45 & 72 & 1.1 & 38 & 12.9 & -18.3 & 37 & $\mathrm{t}$ \\
\hline $\mathrm{F} 4-5^{*}$ & 68.00 & 52.40 & 72 & 1.1 & 45 & 12.9 & -18.3 & 37 & g \\
\hline F6-2* & 64.32 & 59.08 & 225 & 15 & 4 & 14.6 & -22.4 & 49 & $\mathrm{~g}$ \\
\hline F7-3* & 67.12 & 56.68 & 75 & 0.7 & 0.1 & 14 & -20.4 & 43 & $\mathrm{t}$ \\
\hline F7-4* & 67.12 & 56.72 & 78 & 1 & 14 & 14 & -20.4 & 43 & $\mathrm{t}$ \\
\hline F7-5* & 67.13 & 56.68 & 82 & 2.5 & 0.5 & 14 & -20.4 & 43 & $\mathrm{f}$ \\
\hline F8-2 & 67.87 & 59.72 & 23 & 3.5 & 0.2 & 12.9 & -21.4 & 43 & $\mathrm{t}$ \\
\hline $\mathrm{F} 8-4^{*}$ & 67.88 & 59.67 & 15 & 6 & 0.1 & 12.9 & -21.4 & 43 & g \\
\hline TDRA $2^{*}$ & 65.98 & 60.02 & 59 & 6.6 & 36 & 14.6 & -21.7 & 47 & $\mathrm{~g}$ \\
\hline TDRC 2* & 66.10 & 60.25 & 50 & 1.7 & 135 & 14.6 & -21.7 & 47 & g \\
\hline TDRD 2* & 67.12 & 59.57 & 110 & 5.2 & 42 & 13.2 & -21.7 & 44 & g \\
\hline TDRE $1 *$ & 65.25 & 59.67 & 514 & 17 & 6 & 11.6 & -24.8 & 48 & $\mathrm{~g}$ \\
\hline TDRU11a & 67.45 & 63.08 & 60 & 1.7 & 44 & 12.8 & -23.8 & 47 & $\mathrm{~g}$ \\
\hline TDRU 42a* & 65.97 & 57.27 & 116 & 8.7 & 43 & 15.5 & -20.4 & 46 & $\mathrm{~g}$ \\
\hline Mitrofanovskoe & 67.85 & 58.98 & 132 & 20 & 31 & 12.5 & -21.5 & 42 & $\mathrm{~g}$ \\
\hline Vanuk-Ty & 68.00 & 62.75 & 124 & 25 & 830 & 12.6 & -23.3 & 45 & g \\
\hline Bol'shoy Kharbey & 67.53 & 62.88 & 100 & 18 & 2130 & 12.9 & -23.6 & 46 & $\mathrm{~g}$ \\
\hline
\end{tabular}

* Lakes do not have official names and in our article we use the field codes.

lakes do not have official names and were numbered in the field by their distance from the center of the transect (Table 1). Cores of sediments were collected using Glew sampler (Glew, 1989) from the deepest part of the lake and cut into layers of $0.5 \mathrm{~cm}$ in the field. In our study we analyzed only the surface layers of sediments $(0-0.5 \mathrm{~cm})$. More information on sampling methods and chemical analysis of the investigated lakes can be found in earlier publications (Solovieva et al., 2002, 2005, 2008).

The lakes have glacial, thermokarst or floodplain origin. Most lakes are low-conductivity, with $\mathrm{pH}$ between 6 and 7, and oligotrophic with prevailing bicarbonate-calcium water composition (Table 1). Two lakes are acidified with pH 5.73 and 5.14 (Kharkevich, 1970).

Short sediment core for palaeoecological studies was collected in the southern part of the B. Kharbey Lake from the depth of $6 \mathrm{~m}$ during summer expedition in 2012 (Nazarova et al., 2014) (Fig. 1) using sampler UWITEC (Austria). The surface layer of sediments of the B. Kharbey Lake was included in the analysis of the modern fauna, along with 22 lakes sampled earlier. Bol'shoi Kharbey Lake (surface area-21.3 $\mathrm{km}^{2}$ ) is located in the eastern part of the Bolshezemelskaya tundra $\left(67^{\circ} 33^{\prime} 22^{\prime \prime} \mathrm{N}, 62^{\circ} 53^{\prime} 23^{\prime \prime} \mathrm{E}\right)$. The lake has glacial origin, watershed is swampy (Zverev et al., 1970). During our expedition at the end of July-early August the water temperature was $9.6-13.0^{\circ} \mathrm{C}$. Mean July temperature $12.9^{\circ} \mathrm{C}$ (New et al., 2002). The greatest depth $(18.5 \mathrm{~m})$ was recorded in the southern part of the lake, but most of the lake is $3-6 \mathrm{~m}$ deep.

Sixteen environmental parameters were included in the statistical analysis (Table 2). Mean July $\left(\mathrm{T}_{\text {July }}\right)$, and the mean January ( $\left.\mathrm{T}_{\text {January }}\right)$ temperature used in our analysis, were calculated on the basis of "The Gridded Climate Data” (New et al., 2002). Gorczynski continentality Index (CI; Gorczynski, 1920) for each lake was calculated by a formula in modification of Greaser et al. (Grieser et al., 2006): $\mathrm{CI}=1.7(\mathrm{~A} / \sin \varphi)-20.4$. 
Table 2. Statistical summary of the limnological measurements and geographical parameters of the study lakes from the Pechora basin. SD—standard deviation, Skew—skewness

\begin{tabular}{l|c|c|c|c|c|c|c}
\hline \multicolumn{1}{c|}{ Variable } & Min & Max & Mean & median & SD & Skew & B. Kharbey \\
\hline Latitude, N & 64.32 & 68.00 & 67.23 & 67.85 & 1.00 & -1.56 & 67.5 \\
Longitude, E & 52.38 & 63.08 & 57.40 & 57.27 & 3.40 & 0.03 & 62.88 \\
Altitude (m, asl) & 4.8 & 514.0 & 86.6 & 72.0 & 104.5 & 3.2 & 100 \\
$\mathrm{~T}_{\text {July }}{ }^{\circ} \mathrm{C}$ & 11.6 & 15.5 & 13.4 & 13.3 & 0.9 & 0.6 & 12.9 \\
$\mathrm{~T}_{\text {January, }}{ }^{\circ} \mathrm{C}$ & -24.8 & -18.3 & -20.8 & -20.4 & 1.9 & -0.4 & -23.6 \\
$\mathrm{CI}$ & 36.8 & 49.4 & 42.7 & 43.1 & 3.8 & -0.06 & 46 \\
Water depth, m & 0.7 & 25.0 & 6.7 & 3.5 & 7.0 & 1.4 & 18 \\
$\mathrm{~S}$ ha & 0.10 & 2130.0 & 153.4 & 28.0 & 452.9 & 4.0 & 2130 \\
$\mathrm{Conductivity}^{\prime \mu S \mathrm{Sm}^{-1}}$ & 2.4 & 116.0 & 32.7 & 20.5 & 28.4 & 1.3 & 27 \\
$\mathrm{pH}^{-1}$ & 5.14 & 7.60 & 6.81 & 6.90 & 0.54 & -1.47 & 7.1 \\
$\mathrm{Cl}^{-}, \mathrm{mg} \mathrm{L}^{-1}$ & 0.20 & 6.75 & 2.24 & 1.81 & 1.42 & 1.56 & 0.6 \\
$\mathrm{SO}_{4}^{2-}, \mathrm{mg} \mathrm{L}^{-1}$ & 0.26 & 4.19 & 1.37 & 1.00 & 1.07 & 1.78 & 1.3 \\
$P_{\text {tot }}, \mathrm{mg} \mathrm{L}^{-1}$ & 1.0 & 97.0 & 26.2 & 16.0 & 25.8 & 1.55 & 1 \\
$\mathrm{Ca}^{2+}, \mathrm{mg} \mathrm{L}^{-1}$ & 0.94 & 30.00 & 6.02 & 3.53 & 6.59 & 2.43 & 0.66 \\
$\mathrm{Mg}^{2+}, \mathrm{mg} \mathrm{L}^{-1}$ & 0.18 & 4.19 & 1.25 & 1.06 & 0.98 & 1.53 & 0.69 \\
$\mathrm{Na}^{+}, \mathrm{mg} \mathrm{L}^{-1}$ & 0.29 & 4.77 & 1.85 & 1.89 & 1.10 & 0.75 & 2.5 \\
\hline
\end{tabular}

Where $\mathrm{A}$ is annual difference in temperatures in ${ }^{\circ} \mathrm{C}$ and $\varphi$ - lake Latitude. In our study, we took the difference between the mean July and mean January temperatures.

Age model of the core from the B. Kharbey Lake. The core was sectioned at $1 \mathrm{~cm}$ intervals for further analysis in the field. Selected sediment intervals were ${ }^{210} \mathrm{~Pb}$-dated at Geochronology Laboratory at St. Petersburg State University. The age-depth model for the core is based on ${ }^{210} \mathrm{~Pb}$ dates and was made with the Bacon 2.2 package (Blaauw and Christen, 2011) of R software (R Development Core Team, 2012).

Chironomid analysis. Treatment of sediment samples for chironomid analysis followed standard techniques (Brooks et al., 2007). To capture the maximum diversity of the chironomid population, 110 to $560 \mathrm{chi}-$ ronomid larval head capsules were extracted from each sample. Larval head capsules were mounted two at a time in Euparal or Hydromatrix. In total, 3617 chironomid head capsules were slide mounted and identified. Chironomids were identified to the highest taxonomic resolution possible with reference to modern identification manuals (Brooks et al., 2007; Wiederholm, 1983).

Data on ecological preferences of chironomid taxa have been taken from Brooks et al. (Brooks et al., 2007), and chironomid data bases on Northern Russia and Far East (Nazarova et al., 2008, 2011, 2015).

Statistical analysis. Only taxa that have abundances at least $2 \%$ in at least 2 lakes were retained for statisti- cal analyses and 72 of 96 were included in the analysis. Detrended correspondence analysis (DCA) was performed on the chironomid data (rare taxa downweighted) to determine the length of the sampled environmental gradients, reflecting $\beta$-diversity of the studied chironomid communities (Birks, 1995) and from which we decided whether unimodal or linear statistical techniques would be the most appropriate for the data analysis (ter Braak and Prentice, 1988).

The gradient length of the DCA axis 1 (data were square-root transformed prior to analysis) was 1.84 standard deviation units, indicating that numerical methods based on a lineal response model (RDA) were the most appropriate to assess the variation of the chironomid assemblages (ter Braak and Verdonschot, 1995; ter Braak, 2002a).

In order to reduce the error in ordination environmental variables with skewed distributions (area, conductivity, $\left.\mathrm{Ca}^{2+}, \mathrm{Mg}^{2+}, \mathrm{SO}_{4}^{2-}, P_{\text {total }}\right)$ were transformed using $\ln (x+1)$, where $\mathrm{x}$ was the given environmental variable.

Variance inflation factors (VIF) were used to identify the intercorrelated variables. Environmental variables with a VIF greater than 20 were eliminated, beginning with the variable with the largest inflation factor, until all remaining variables had values of $<20$ (ter Braak and Šmilauer, 2002a). Minimal subset of the ecological parameters, which explains variation in chironomid assemblages, was then tested using forward selection method. Manual forward selection was 
Table 3. Concentration of ${ }^{210} \mathrm{~Pb}$ and age of the sediment layers from the B. Kharbey Lake

\begin{tabular}{c|c|c}
\hline Depth, cm & $\begin{array}{c}\text { Concentration } \\
210 \mathrm{~Pb}, \mathrm{~Bq} \mathrm{~kg}^{-1}\end{array}$ & Age, years \\
\hline $0-1$ & $360 \pm 21$ & $3.7 \pm 0.3$ \\
$2-3$ & $220 \pm 14$ & $18.6 \pm 1.7$ \\
$4-5$ & $166 \pm 12$ & $33.6 \pm 3.0$ \\
$7-8$ & $101 \pm 7$ & $56.0 \pm 5.0$ \\
$9-10$ & $38.7 \pm 4.7$ & $70.9 \pm 6.3$ \\
$11-12$ & $20.6 \pm 4.0$ & $85.8 \pm 7.6$ \\
$14-15$ & $10.1 \pm 1.4$ & $108.2 \pm 9.6$ \\
$19-20$ & $4.7 \pm 0.7$ & $149 \pm 13$ \\
$22-23$ & $3.2 \pm 0.7$ & - \\
$24-25$ & $1.5 \pm 0.8$ & - \\
\hline
\end{tabular}

used to identify a subset of environmental variables that explained significant variations in the chironomid data. Statistical significance of each forward-selected variable was tested by a Monte Carlo permutation test (999 unrestricted permutation, $P \leq 0.05$ ) (ter Braak, 1990).

Mean July air temperature $\left(\mathrm{T}_{\text {July }}\right)$ and water depth (WD) were reconstructed using Russian chironomidbased inference statistical models (Nazarova et al., 2011, 2015; Self et al., 2011) using program C2 (Juggins, 2007). Lower horizons of the core contained too few chironomid head capsules for reliable reconstruction and were excluded from the analysis.

In order to further explore the relationship between training set analogues and the B. Kharbey subfossil sequences the data were combined and analysed using a 'time-track' RDA with the B. Kharbey samples plotted passively (Nazarova et al., 2013).

Ordination was performed in CANOCO 4.5 (ter Braak and Šmilauer, 2002b). Stratigraphic diagram was done in C2 (Juggins, 2007). Statistically significant zones were divided using programms BSTICK and ZONE (Lotter and Juggins, 1991; Bennett, 1996) and DCA axes 1 and 2. Diversity and evenness of the chironomid communities were estimated using Shannon (H) (Shannon, 1963) and Pielou (I) (Pielou, 1966) indices.

\section{RESULTS Age-Depth Model}

Data on the content of ${ }^{210} \mathrm{~Pb}$ in the core are presented in the Table 3. Concentrations of ${ }^{210} \mathrm{~Pb}$ in the core decrease exponentially with the depth, which is determined by half-life of ${ }^{210} \mathrm{~Pb}\left(\mathrm{~T}_{1 / 2}=22.2\right.$ years $)$. The mean sedimentation rate calculated for the first $20 \mathrm{~cm}$ of the core is $1.34 \pm 0.12 \mathrm{~mm} \mathrm{yr}^{-1}$ and, accordingly, the age of $19-20 \mathrm{~cm}$ layer is $149 \pm 13$ years.
Deeper layers $(22-23$ and $24-25 \mathrm{~cm})$ contain only small amounts of ${ }^{210} \mathrm{~Pb}$ showing almost complete decay of this radionuclide during the $\sim 150$ years, which is the age limit for the ${ }^{210} \mathrm{~Pb}$ method (Fig. 2).

\section{Modern Chironomid Fauna of the Lakes}

Thirty seven taxa belong to the subfamily Chironominae ( 22 from the tribe Chironomini, 15 from the tribe Tanytarsini), 52 taxa belong to the subfamily Orthocladiinae, 4 to Tanypodinae, 3 to Diamesinae. Full list of subfossil chironomid taxa from the studied lakes is published in PANGEA database (https:// doi.pangaea.de/10.1594/PANGAEA.868888).

The most common taxa are Psectrocladius sordidellus-type, Microtendipes pedellus-type, Tanytarsus pallidicornis-type, Paratanytarsus penicillatus-type, Sergentia coracina-type, Chironomus anthracinus-type, Limnophyes - Paralimnophyes, Cladotanytarsus mancus-type, Micropsectra insignilobus-type, Zalutschia zalutschicola.

\section{Influence of Ecological Factors on Chironomid Distribution}

RDA with all environmental parameters showed that latitude, longitude, water depth, conductivity, $\mathrm{T}_{\text {July }}, \mathrm{T}_{\text {January }}, \mathrm{CI}, P_{\text {tot }}$ were intercorrelated and therefore these parameters were removed from the analysis one by one until all VIFs became below 20. A minimal subset of not correlated environmental parameters included CI, $\mathrm{T}_{\text {July }}$, water depth, $\mathrm{pH}$, conductivity, and lake area. Monte Carlo test (999 permutations) showed that significant role in the distribution of chironomids $(P \leq 0.05)$ played $\mathrm{CI}, \mathrm{pH}$ and $\mathrm{T}_{\text {July }}$.

The eigenvalues of the RDA axes 1 and $2(\lambda 1=0.148$ and $\lambda 2=0.071)$ of three significant variables constitute 88.6 and $76.3 \%$ of eigenvalues of the RDA axes 1 and 2 of the full set of the known environmental variables $(\lambda 1=0.167$ and $\lambda 2=0.093)$, suggesting that removing of correlated and insignificant variables had little impact on the effectiveness of the analysis. According to Juggins (2013) the ratio of the eigenvalues of the RDA axes 1 and 2 below 1 implies that not all important environmental parameters are included in the analysis. In our case the ratio is $2.08(\lambda 1 / \lambda 2=$ $0.148 / 0.071)$, indicating that all most important parameters are included in the analysis.

RDA has shown (Fig. 3) that a group of lakes of a glacial origin positively correlates with the CI. Typical for this group of the lakes are profundal, cold stenotherm oligotrophic taxa: Heterotrissocladius subpilosus-type, Hydrobaenus conformis-type, Monodiamesa, Parakiefferiella nigra-type, Paratanytarsus penicillatus-type, Stictochironomus. The fauna of the floodplain and thermokarst lakes is more related to the $T_{\text {July }}$ and is represented by the taxa typical for littoral of relatively warm and more productive lakes with macro- 

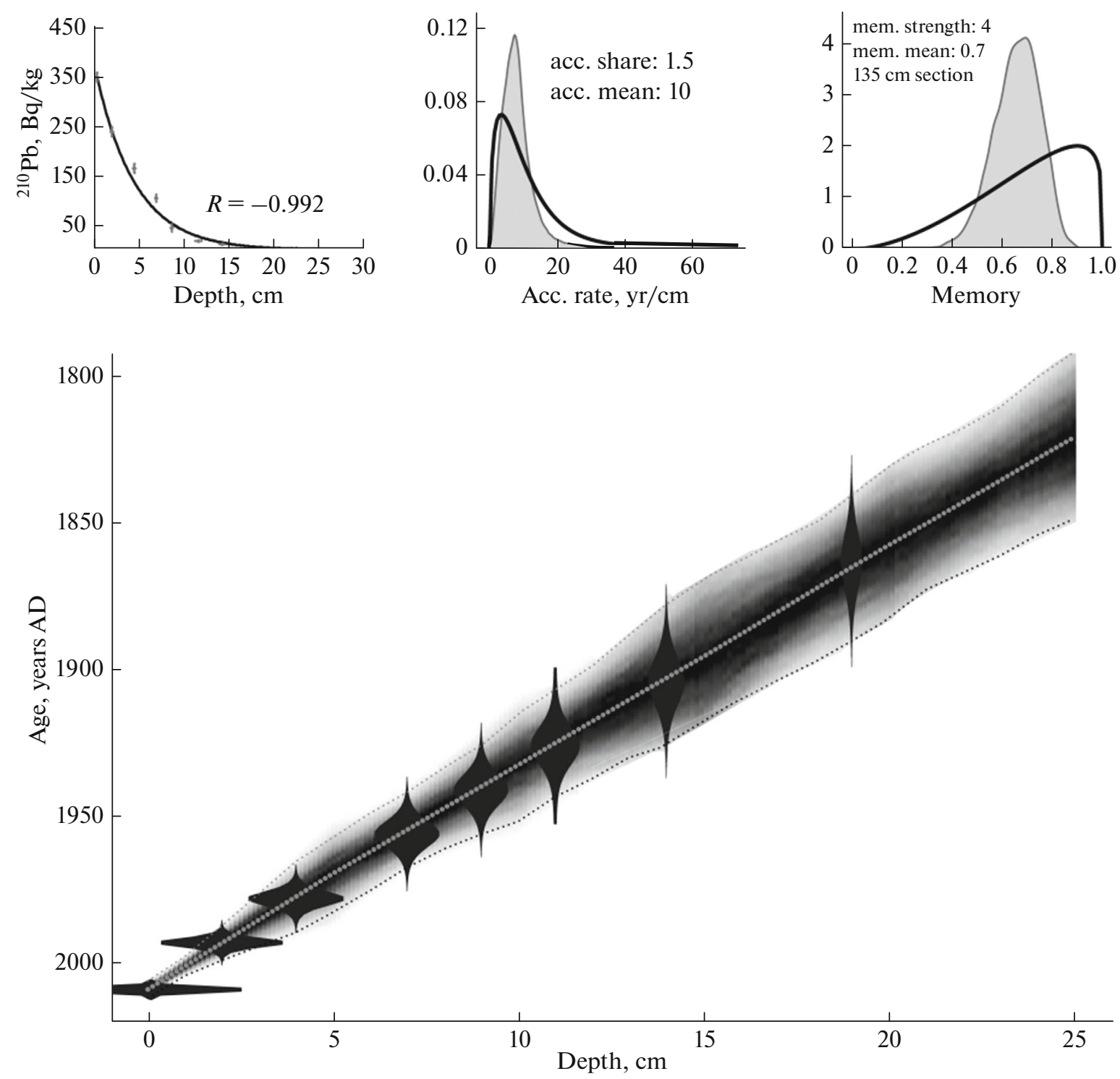

Fig. 2. Age model of the sediment core from the B. Kharbey Lake.

phyte belts, and some of the taxa can tolerate acid conditions: Tanytarsus pallidicornis-type, Glyptotendipes pallens-type, Corynocera ambigua, Cladotanytarsus mancus-type, Endochironomus albipennis-type. Fauna of two acidified thermokarst lakes (F7-4 and F7-3) is dominated by Psectrocladius sordidellus-type, Psectrocladius septentrionalis-type, Zalutschia zalutschicola, Limnophyes-Paralimnophyes, Corynoneura arctica-type.

\section{Chironomid Analysis of the Sediment Core from B. Kharbey Lake}

We found 38 chironomid taxa in the core, with 19 belonging to the subfamily Chironominae (10 from the tribe Chironomini, 9 from the tribe Tanytarsini), 17 taxa belonged to the subfamily Orthocladiinae, 2 to Tanypodinae, and 2 to the subfamily Diamesini.
M. insignilobus-type was found in all investigated horizons of the core. This taxon is characteristic of oligotrophic waters of cold regions and, probably, is acidophobic (Bitušik and Kubovcik, 1999). Common taxa comprise tolerant to acidification $H$. grimshawi-type, $H$. marcidus-type, and H. maeaeri-type; indicative of moderate temperatures littoral-sublittoral Microtendipes pedellus-type, and usually quite rare in the Russian Arctic taxon Constempellina-Thienemanniola (Nazarova et al., 2015), which is, attributed to lentic and lotic ecosystems (Brooks et al., 2007). Full list of taxa of chironomids taxa from the core is published in the database PANGEA (https://doi.pangaea.de/ 10.1594/PANGAEA.865075).

Indices describing qualitative characteristics of the chironomid communities in the investigated horizons of the core show little variability (Fig. 4). Evenness (I), a function of stability of chironomid communities, 


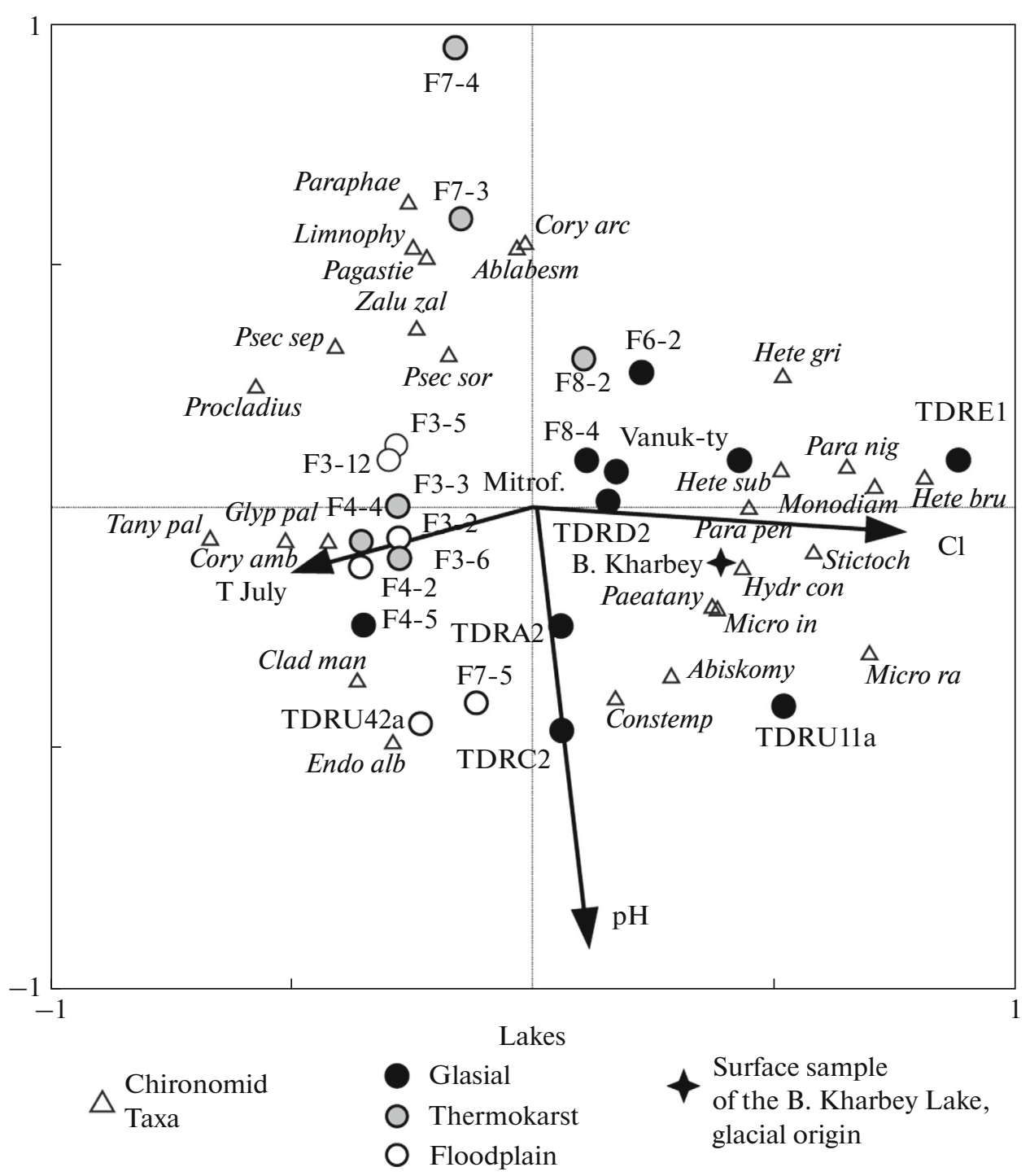

Fig. 3. RDA plot of the significant environmental variables, investigated lakes and common chironomid taxa. $\mathrm{T}_{\mathrm{July}}-\mathrm{mean}$ July air temperature (New et al., 2002), CI-Gorczynski continentality index (Grieser et al., 2006).

remains quite high in the whole core, averaging at $0.7 \pm 0.1$. Only sediment layers at the depths of $13-$ $19 \mathrm{~cm}$ (up to 1910) are characterized by slightly lower Evenness (I) of chironomid communities. The number of chironomid taxa, and the Shannon diversity index increased towards the top of the core.

Three statistically significant chironomid assemblage zones (Ch I-III) corresponded to trends in the sample scores of the first two DCA axes (Fig. 4).

Ch I (24-19 cm, AD 1840-1880). On average, there are 12 taxa per sample, with Shannon diversity $(\mathrm{H})$ reaching 2.14. The dominant taxa are $M$. pedellustype, the abundance of which gradually increases toward the end of the zone from 19 to $31 \%, M$. insignilobus-type, $H$. grimsshawi-type and $H$. maeaeri-types 1 and 2 that slightly decrease at the upper part of the zone. The maximum $\mathrm{T}_{\text {July }} \sim 13.2^{\circ} \mathrm{C}$ is reconstructed between AD 1840 and 1860. Around AD $1870 \mathrm{~T}_{\text {July }}$ decreases to $11.4^{\circ} \mathrm{C}$. Water depths in this zone slightly vary around $7.5 \mathrm{~m}$, which is higher than at present (Fig. 4).

Ch II (19-9 cm, AD 1880-1980). The average number of taxa per sample is 19 , while in the upper layers of the zone taxonomic richness increases and reaches 24 taxa per sample. At the lower part of the zone the average value of $\mathrm{H}$ is 2.27 , and it increases gradually toward the top of the zone up to 2.8. After AD 1880, the abundance of $M$. pedellus-type drops sharply while $M$. insignilobus-type becomes dominant, although its abundance gradually declines towards the upper layers of the core together with the abundances of several acid-tolerant Heterotrissocladius taxa (H. macridus-type, H. maeaeri-type, H. grimschawitype). Constempellina-Thienemanniola became quite 


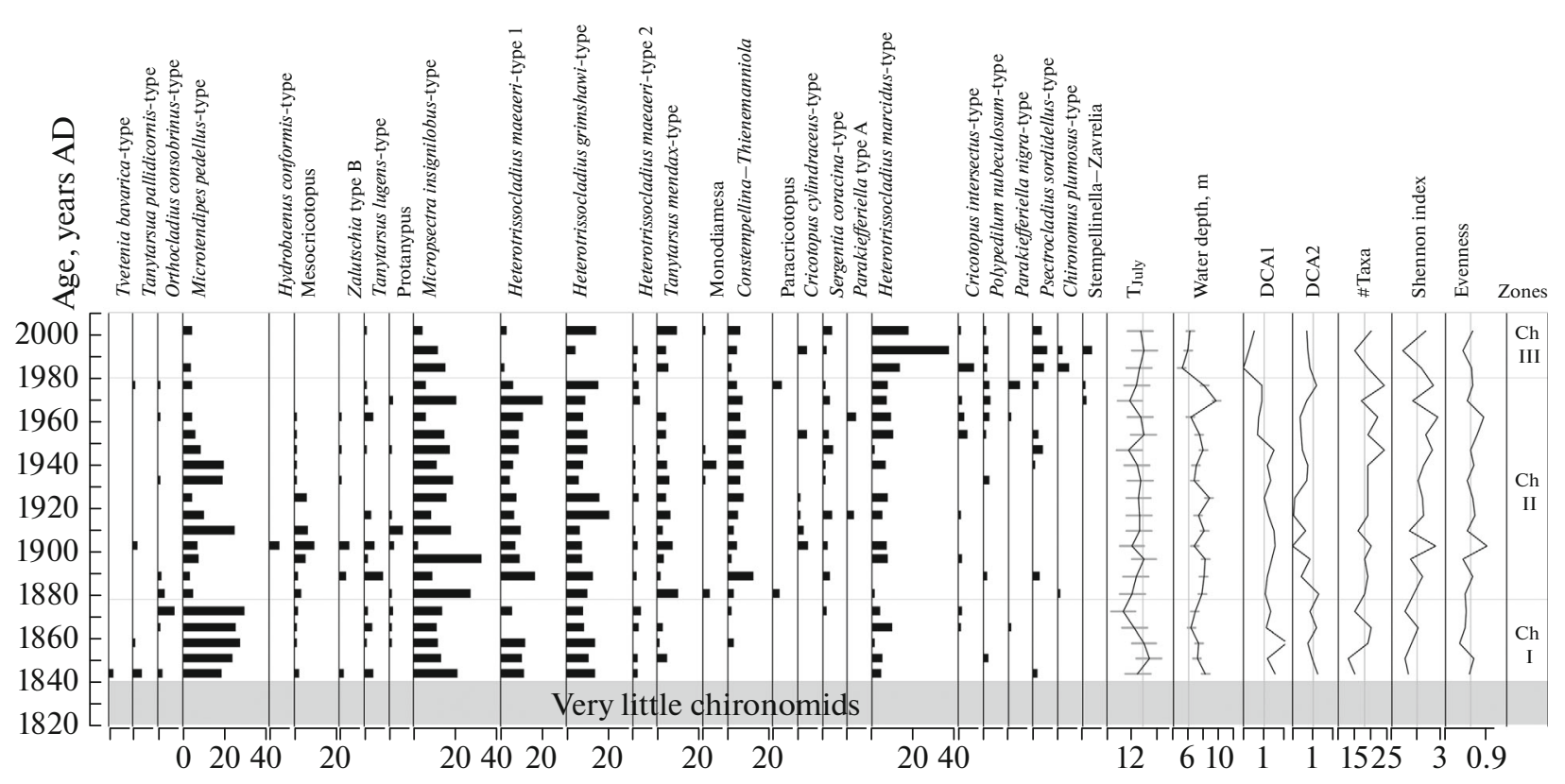

Fig. 4. Stratigraphic diagram showing distribution of the main chironomid taxa, reconstructed mean July air temperature $\left(\mathrm{T}_{\mathrm{July}},{ }^{\circ} \mathrm{C}\right)$, water depth $(\mathrm{m})$, variations of DCA axes 1 and 2 and qualitative parameters of chironomid communities in the sediment core from the B. Kharbey Lake.

frequent within $\mathrm{CH}$ II. Reconstructed temperatures are slightly lower than at present (average for the period $\mathrm{T}_{\mathrm{July}}=12.3 \pm 0.5^{\circ} \mathrm{C}$ ). The reconstructed water depths remain above present level and average at $8.1 \pm$ $0.9 \mathrm{~m}$. Species composition of chironomid communities in this zone indicates some decrease in water acidity, which may be associated with the rise of the water level in the lake.

Ch III (9-0 cm, AD 1980-2010). The average number of taxa per sample is 18 , which increases to 20 in the upper horizon The average values of $\mathrm{H}=2.53$. The abundance of acidophilic Heterotrissocladius, and, especially, H. macridus-type, which is the most thermophilic taxon, increase. Abundances of other thermophilic taxa whith high nutrient demands increase as well: Tanytarsus mendax-type, $P$. sordidellustype and Chironomus plumosus-type. In this zone abundances of phytophilic taxa (Cricotopus intersectus-type, C. cylindraceus-type) also increase. This change in species composition may indicate warming, shallowing, possible paludification of the littoral zone of the lake and spreading of submerged and coastal aquatic vegetation. The reconstructed depths of the lake are lowering, and $\mathrm{T}_{\text {July }}$ grows to the present level $(\mathrm{WD}=6 \mathrm{~m}$, $\mathrm{T}_{\text {July }}=12.9^{\circ} \mathrm{C}$ ).

Comparison of the chironomid taxonomic composition of the core from the B. Kharbey Lake with the modern chironomid communities of the lakes from the Pechora river basin (Fig. 5) shows that the analogues of the lake communities from the B. Kharbey are well represented in the modern fauna. The chiron- omid communities of the B. Kharbey Lake during the period of sedimentation are similar to the fauna of the deeper glacial lakes (depth 5.2-25 m), that are also characterized by the highest in the data set continentality indices (45-49), and lower winter temperatures $\left(-21.5 \ldots-24.8^{\circ} \mathrm{C}\right)($ Table 1$)$.

\section{DISCUSSION}

Our investigation showed that the chironomid fauna of the region is dominated by mostly cold stenotherm, acid-tolerant taxa that are quite widespread in fossil chironomid communities of Russian Arctic. Earlier studies have shown high similarity between the chironomid fauna from Pechora river basin and faunas of the lakes from the Putorana plateau and the Kolyma river basin (Siberia, Russia) (Nazarova et al., 2015).

We found differences between chironomid faunas of the lakes of different origin. Typical of glacial lakes, that are characterized by greater depths $(5.2-25 \mathrm{~m})$, highest in the dataset CI (45-49) and lower winter temperatures $\left(-21.5 \ldots-24.8^{\circ} \mathrm{C}\right)$ (Table 1) are cold stenotherm taxa preferring profundal zone of oligotrophic lakes. Among the dominant in the glacial lakes $M$. radialis-type and $M$. insignilobus-type are regarded as acidophobic and $H$. maeaeri-type and $H$. subpilosus-type as acidophilic. Given the association of these taxa to the weakly alkaline and weakly acidic lakes (6.7-7.6) respectively, and low species scores of these taxa along RDA 2 axis, which is mainly associated with 


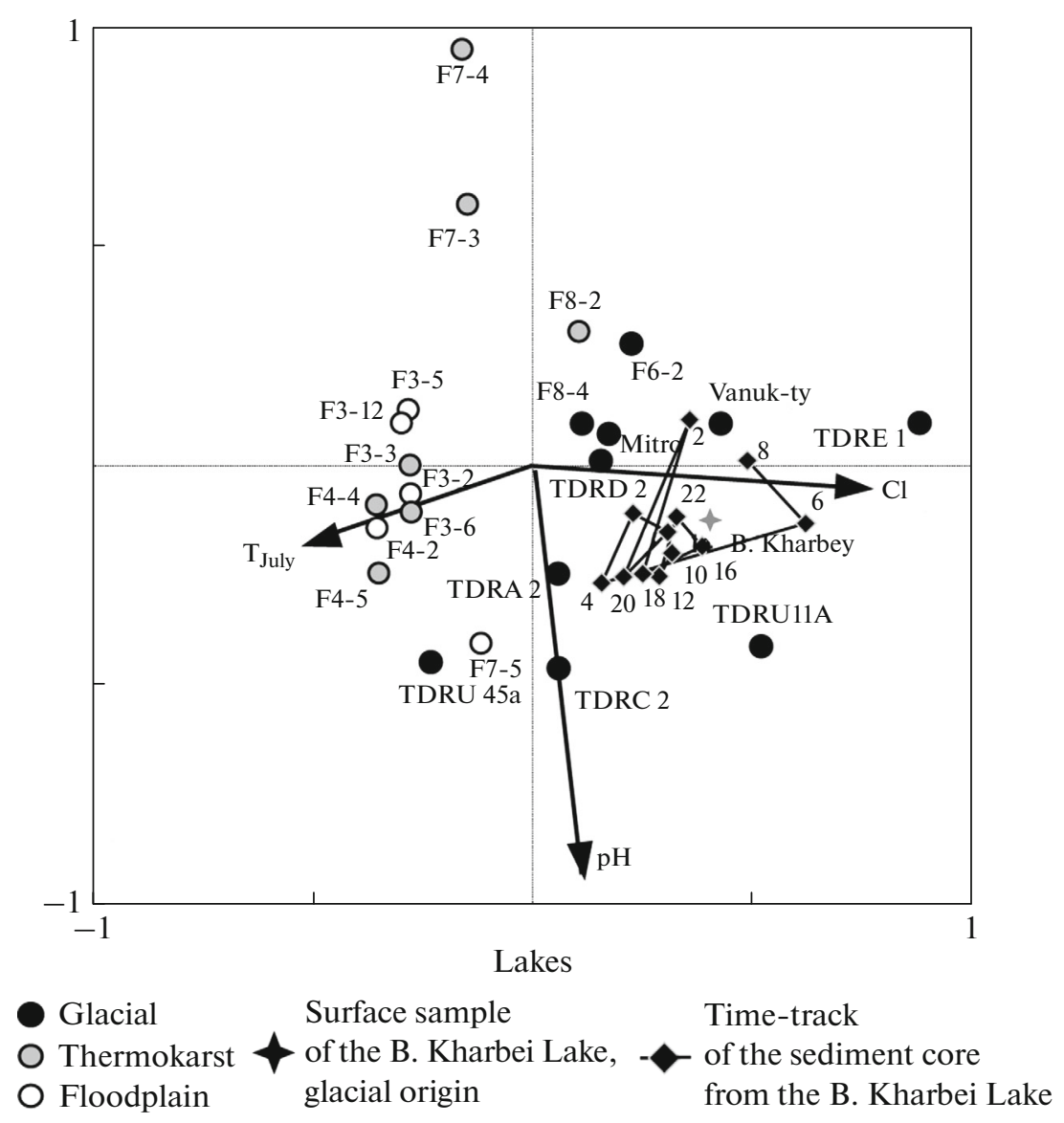

Fig. 5. RDA time-track plot showing the significant environmental variables and Pechora River basin lakes compared against fossil samples from B. Kharbei Lake which have been plotted passively. B. Kharbei Lake samples are numbered starting from the top of the core $(2-22)$.

pH (Fig. 3) we suppose that their presence in the samples is not related to $\mathrm{pH}$, but to low temperatures.

The fauna of the floodplain and thermokarst lakes is represented by phytophilic littoral taxa of meso- to eutrophic waters, which prefer warmer conditions.

Fauna of acid thermokarst lakes (F7-4 and F7-3) is significantly different from other lakes and is represented by typical acid-tolerant taxa Ablabesmyia, $P$. sordidellus-type, $\quad P$. septentrionalis-type, and $Z$. zalutschicola, and also by typically littoral and shallow taxa Parachaetocladius, Limnophyes - Paralimnophyes, Pagastiella, Corynoneura arctica-type, which apparently are able to tolerate acid waters.

Since the investigated lakes are located outside of the zone of anthropogenic impact, the chemical composition of lake water is determined only by natural factors: underlying soils, origin of their basins, surface runoff, hydrological and temperature regimes (Goldin 1972). Analysis of the influence of environmental factors on distribution of chironomid taxa in the region showed that the most important parameters are $\mathrm{pH}$, $\mathrm{CI}$ and $\mathrm{T}_{\text {July. }}$
Most of the investigated lakes are slightly acidic. $\mathrm{pH}$ value in lakes, as in all natural waters, depends on the contents of different forms of carbonic acid, mainly on hydrocarbon ions. In natural waters $\mathrm{HCO}^{3-}$ ions are produced by dissociation of $\mathrm{Ca}\left(\mathrm{HCO}_{3}\right)_{2}$ and $\mathrm{Mg}\left(\mathrm{HCO}_{3}\right)_{2}$, which increases the concentration of $\mathrm{HCO}^{3-}$, and lead to decrease of concentration of $\mathrm{H}^{+}$, and increase in $\mathrm{pH}$ towards the alkaline reaction, i.e. appearance $\mathrm{OH}^{-}$ions (Nikanorov, 2001). A similar pattern is typical for the studied lakes. A strong correlation between mineralization and $\mathrm{pH}$ (Dauvalter and Khloptseva, 2008) was also observed. Weakly mineralized waters of thermokarst lakes have lower $\mathrm{pH}$ values. Ammonia nitrogen, nitrate and nitrite were not found in the investigated lakes which in general is characteristic of waters of the region, considering slow rate of nitrification and ammonification at low temperatures (Dauvalter and Khloptseva, 2008).

Low $\mathrm{pH}$ causes many changes in water ecosystems that potentially impact aquatic organisms (Kharkevich, 1970). Under pH below 7.0 organic acids do not dissolve in the water and deposit into sediments, forming silt (humic sapropel) (Kharkevich, 1970). Phyto- 
plankton and zooplankton of acidified lakes have often low abundances, caused by low availability of nutrients (Palagushkina et al., 2012; Frolova et al., 2013, 2016). It is known that the $\mathrm{pH}$ influences the diversity and abundance of benthic communities, including chironomids. As many chironomid species are primary consumers feeding on algae and detritus, and build an important link between the allochthonous and autochthonous primary production and the higher trophic levels in aquatic ecosystems their physiological processes are particularly affected by biochemical mechanisms of active ion transport in the waters they inhabit (Klishko, 2003). Studies have shown that low $\mathrm{pH}$ values do not always cause any significant reduction in biomass of chironomid communities, but cause changes in their structure and reduction in species diversity (Woodcock et al., 2005).

A set of significant environmental variables explaining distribution of chironomids in the lakes of the region includes two climatic parameters: $\mathrm{T}_{\text {July }}$ and continentality index CI. To date, there are numerous publications that documents effect of climate in general and air temperature in particular on chironomid larvae. For instance, relationship between temperature and distribution of chironomids was used to produce chironomid-based temperature models (Barley et al., 2006; Self et al., 2011), and to reconstruct summer temperatures during Holocene (Brooks and Birks, 2000) and in the earlier time intervals (Kienast et al., 2011; Nazarova et al., 2012). Relationship between continentality, plant communities (Giesecke et al., 2008) and soil composition (Kazeev et al., 2015) is widely known in ecology. There are differences in daily temperature amplitudes, humidity, precipitation and other parameters between maritime and continental climates. Clearly climate continentality is reflected by the annual range of temperatures, which also depends on the latitude. At low latitudes, the annual temperature amplitude is lower compared to high latitudes, even in continental areas. Although the impact of continentality on plant communities is better understood compared to insects, recent studies have shown importance of this parameter for distribution of chironomids in lakes of northern Eurasia (Self et al., 2011). Analysis of the database including 149 lakes from Norway to the Lena river delta (Northern Yakutia, Russia) revealed that CI didn't correlate with $\mathrm{T}_{\text {July }}$ $(r=0.11)$, but statistically significantly correlated with $\mathrm{T}_{\text {January }}(r=-0.98)$. In our study CI also significantly correlated with $\mathrm{T}_{\text {January }}(r=-0.88)$ and only to a minor extent with $\mathrm{T}_{\text {July }}(r=0.30)$. Since in winter chironomids have diapause, they cannot respond directly to winter temperatures. They rather respond to other parameters associated with low winter temperatures, such as, for example, insolation level, limited availability of food resources, or duration of the ice-free period which physically limits the time available for active generation development of chironomids.
The results of the analysis of the short sediment core from the B. Kharbei Lake showed that the overall changes in the structure of chironomid communities over the past $c a 200$ years indicated only minor changes in environmental conditions. Reconstructed $\mathrm{T}_{\text {July }}$ were slightly lower than today over the entire period. Minimum temperatures were reconstructed for AD 1870th and 1970th. Since 1970th we reconstructed a steady trend of $T_{\text {July }}$ rising to the present values. Similar dynamics was reconstructed from the chironomid record of another lake from the region, lake Mitrofanovskoe (Solovieva et al., 2005), in which, after AD 1984, the chironomid fauna had the highest number of thermophilic taxa such as Dicrotendipes, Tanytarsus pallidicornis-type and Cricotopus type B. The reconstructed temperatures gradually increased from the middle of the 19th century, but the largest increase in $\mathrm{T}_{\text {July }}$ was reconstructed for the last decade of the 20 th century, when the temperatures reached the modern level.

Reconstructed water depths in B. Kharbey Lake were higher than the modern level until 1980. The highest depth was reconstructed around 1970. Thereafter water level in the lake gradually declined and reached the modern level. According to observations of the Institute of Biology of Komi SC UrRAS (Syktyvkar, Russia) the maximal depth $(18.5 \mathrm{~m})$ was recorded in the southern part of the lake between 1968 and 69. Between 1998 and1999 the highest recorded depth was $16 \mathrm{~m}$, and 2009-2010 it was only $9.8 \mathrm{~m}$ (Baturin et al., 2012), although it is possible that the maximum depth was not measured. The sediment core in the study was collected from the depth of $6 \mathrm{~m}$, and therefore the chironomid-reconstructed fluctuations of the water level may not reflect the maximum lake depth, but only depths at the place the coring. The changes in the lake depth may also be related to the dynamics of precipitation in the region. According to the data from Vorkuta weather station (Vorkuta..., 2011) the wettest period was observed between 1962 and 1968 with the precipitation rate $624 \pm 98 \mathrm{~mm} /$ year, while an average precipitation rate during the whole period of observation from AD 1949 to 2009 was $533 \mathrm{~mm} /$ year. Lowering of the water level in the lake in the late 1980s is consistent with the decrease in precipitation in the region since the mid-1980th and 1990th when it was averaging at $500 \mathrm{~mm} /$ year, and in some years did not exceed $350 \mathrm{~mm} /$ year (Vorkuta..., 2011).

\section{CONCLUSION}

The most common chironomid taxa in the lakes of the Pechora river basin are common in subfossil communities throughout the Russian Arctic taxa. We found distinctive differences in faunas of the lakes of different origin. Lakes of a glacial origin are dominated by profundal and cold- stenotherm oligotrophic taxa: H. subpilosus-type, $H$. conformis-type, Monodiamesa, P. nigra-type, P. penicillatus-type, Stictochirono- 
mus. Chironomid fauna of floodplain and thermokarst lakes is represented by more thermophilic littoral taxa, of meso- to eutrophic lakes: T. pallidicornis-type, G. pallens-type, C. ambigua, Cl. mancus-type, E. albipennis-type.

Acidic thermokarst lakes are dominated by acid-tolerant taxa (Ablabesmyia, P. sordidellus-type, P. septentrionalis-type, Z. zalutschicola), and typical littoral and shallow water taxa (Parachaetocladius, LimnophyesParalimnophyes, Pagastiella, C. arctica-type), that apparently also can tolerate acidification. $\mathrm{pH}, \mathrm{T}_{\text {July }}$ and $\mathrm{Cl}$ are the most important factors which influence the distribution of chironomids in lake sediments.

Chironomid-reconstructed $\mathrm{T}_{\text {July }}$ and the variation of the water level in the Lake B. Kharbey during the last $c a 200$ years show little changes until last quarter of the $20^{\text {th }}$ century. Before 1970 the reconstructed $T_{\text {July }}$ is slightly lower than at present, and after 1970 it rises to the modern level. The water depth of the lake was higher than at present until 1980, thereafter the lake depth gradually decreased and reached the modern level, which most probably is connected to the changes in precipitation regime in the region.

\section{ACKNOWLEDGMENT}

Research was carried out within the frame and under financial support of the grant 16-17-10118 RSF, part of the laboratory work was sponsored by subsidies allocated in the Kazan (Volga) Federal University in order to improve its competitiveness among the world's leading research and educational centers. We warmly thank all participants of research expeditions to the region of investigation.

\section{REFERENCES}

Alerkin, O.A., Drabkova, V.G., and Koplan-Diks, I.S., Eutrophication of continental waters, Mater. III Vsesoyuznogo simposiuma "Antropogennoe evtrofirovanie prirodnyh vod" (Proc. III All-Union Symp. "Anthropogenic Eutrophication of Natural Waters"), Chernogolovka, 1983, pp. 6-9.

Barley, E.M., Walker, I.R., Kurek, J., Cwynar, L.C., Mathewes, R.W., Gajewski, K., and Finney, B.P., A northwest North American training set: distribution of freshwater midges in relation to air temperature and lake depth, J. Paleolimnol., 2006, vol. 36, pp. 295-314.

Baturina, M.A., Loskutova, O.A., Fefilova, E., and Khokhlova, L.G., Zoobenthos of the Bol'shoi Kharbei Lake (Bol'shezemel'skaya tundra): modern status and analysis of retrospective data, Izv. Komi Nauch. Tsentra, Ural. Otd., Ross. Akad. Nauk, 2012, no. 4 (12), pp. 2129.

Bennett, K.D., Determination of the number of zones in a biostratigraphical sequence, New Phytol., 1996, vol. 132, pp. 155-170.

Birks, H.J.B., Quantitative palaeoenvironmental reconstructions, in Statistical Modeling of Quaternary Science
Data. Technical Guide 5, Cambridge: Quat. Res. Assoc., 1995, pp. 161-254.

Bitušik, P. and Kubovcik, V., Sub-fossil chironomids (Diptera: Chironomidae) from the sediments of the Nižné Terianske pleso (High Tatra Mts., Slovakia), Dipterol. Bohemoslov., 1999, vol. 9, pp. 11-20.

Blaauw, M. and Christen, J.A., Flexible paleoclimate agedepth models using an autoregressive gamma process, Bayesian Anal., 2011, vol. 6, pp. 457-474.

Brooks, S.J. and Birks, H.J.B., Chironomid-inferred lateglacial and early-Holocene mean July air temperatures for Kråkenes Lake, western Norway, J. Paleolimnol., 2000, vol. 23, pp. 77-89.

Brooks, S.J., Langdon, P.G., and Heiri, O., Using and identifying chironomid larvae in palaeoecology, in QRA Technical Guide No. 10, London: Quaternary Research Association, 2007.

Dauvalter, V.A and Khloptseva, E.V., Hydrological and hydrochemical features of the lakes in Bol'shezemel'skaya tundra, Vestn. Murm. Gos. Tekh. Univ., 2008, vol. 11, no. 3, pp. 407-414.

Epler, J.H., Identification Manual for the Larval Chironomidae (Diptera) of North and South Carolina. A Guide to the Taxonomy of the Midges of the Southeastern United States, Including Florida, Palatka, FL: North Carolina Dep. Environ. Nat. Res., 2001.

Frolova, L., Subfossil Cladocera (Branchiopoda, Crustacea) in climatic and palaeoenvironmental investigations in Eastern Siberia (Russia), Proc. Conf. SGEM 2016, June 28-July 6, 2016, Albena, 2016, book 4, no. 2, pp. 601-606.

Frolova, L.A., Nazarova, L., Pestryakova, L., and Herzschuh, U., Analysis of the effects of climate-dependent factors on the formation of zooplankton communities that inhabit Arctic lakes in the Anabar River basin, Contemp. Probl. Ecol., 2013, vol. 6, no. 1, pp. 1-11.

Frolova, L., Nazarova, L., Pestryakova, L., and Herzschuh, U., Subfossil cladoceran from sediment in thermokarst lakes in northeastern Siberia, Russia and their relationship to limnological and climatic variables, J. Paleolimnol., 2014, vol. 52, no. 1, pp. 107-119.

Giesecke, T.A.E.B., Chiverrell, R.C., Seppa, H., Ojala, A.E.K., and Birks, H.J.B., Exploring Holocene continentality changes in Fennoscandia using present and past tree distributions, Quat. Sci. Rev., 2008, vol. 27, pp. 1296-1308.

Glew, J.R., A new trigger mechanism for sediment samples, J. Paleolimnol., 1989, vol. 2, pp. 241-243.

Goldina, L.P., Geografiya ozer Bol'shezemel'skoi tundry (Geography of Bol'shezemel'skaya Tundra), Leningrad: Nauka, 1972.

Gorczynski, W., Sur le calcul du degre du continentalisme et son application dans la climatologie, Geogr. Ann., 1920, vol. 2, pp. 324-331.

Grieser, J., Gommes, R., Cofield, S., and Bernardi, M., Data Sources for FAO Worldmaps of Koeppen Climatologies and Climatic Net Primary Production, Rome: Food Agric. Org., 2006.

Juggins, S., C2 Version 1.5 User Guide. Software for Ecological and Paleoecological Data Analysis and Visualization, Newcastle: Newcastle Univ., 2007. 
Juggins, S., Quantitative reconstructions in paleolimnology: new paradigm or sick science? Quat. Sci. Rev., 2013, no. 64, pp. 20-32.

Kazeev, K.Sh., Kozun', Yu.S., Samokhvalova, L.S., and Kolesnikov, S.I., Influence of arid and continental climate on biological properties of soils in the transect Rostov-on-Don-Astrakhan, Izv. Ross. Akad. Nauk, Geogr., 2015, no. 5, pp. 46-53.

Kharkevich, N.S., Hydrodynamic characteristic of acidotrophic lakes of southern Karelia, in Vodnye resursy Karelii i puti ikh ispol'zovania (Water Resources of Karelia and Their Use), Petrozavodsk, 1970, pp. 306314.

Kienast, F., Wetterich, S., Kuzmina, S., Schirrmeister, L., Andreev, A., Tarasov, P., Nazarova, L., Kossler, A., Frolova, L., and Kunitsky, V., Paleontological records prove boreal woodland under dry inland climate at today's Arctic coast in Beringia during the last interglacial, Quat. Sci. Rev., 2011, vol. 30, nos. 17-18, pp. 2134-2159.

Klishko, O.K., Influence of environmental factors on productivity of chironomid larvae in different-type lakes of Transbaikalian region, in Chteniya pamyati V.Ya. Levanidova (Vladimir Ya. Levanidov's Biennial Memorial Meetings), Vladivostok: Dal'nauka, 2003, vol. 2, pp. $127-134$.

Kondrat'eva, T.A., Nazarova, L.B., Loskutova, O.A., and Baturina, M.A., Preliminary results on chironomid fauna (Chironomidae, Diptera, Insecta) of Kharbi Lake, Izv. Sib. Fed. Univ., Biol., 2014, no. 7, pp. 357-371.

Kuzmina, Y., Distribution, phenology and habitat characteristics of Chironomidae (Diptera) of the northeastern part of the European Russia, Norw. J. Entomol., 2001, vol. 48, pp. 199-212.

Loskutova, O.A., Benthos of the lake-river systems of the East European tundra, Tr. Komi Nauch. Tsentra, Ural. Otd., Ross. Akad. Nauk, 2002, no. 169, pp. 44-56.

Lotter, A.F. and Juggins, S., POLPROF, TRAN and ZONE: Programs for Plotting, Editing and Zoning Pollen and Diatom Data, INQUA Comm. Newsl., Cape Town, 1991, no. 6, pp. 4-6.

Makarchenko, E.A., Makarchenko, M.A., Zorina, O.V., and Sergeeva, I.V., Preliminary data on fauna and taxonomy of chironomids (Diptera, Chironomidae) of Russian Far East, in Chteniya pamyati V.Ya. Levanidova (Vladimir Ya. Levanidov's Biennial Memorial Meetings), Vladivostok: Dal'nauka, 2005, no. 3, pp. 394420.

Massaferro, J.I. and Brooks, S.J., Response of chironomids to Late Quaternary environmental change in the Taitao Peninsula, southern Chile, J. Quat. Sci., 2002, vol. 17, pp. 101-111.

Mukhin, N.M., Petrakova, V.M., and Shevchenko, E.Ya., Climate conditions, in Geokriologicheskie usloviya Pechorskogo ugol'nogo basseina (Permafrost Conditions of the Pechora Coal Basin), Moscow: Nauka, 1964, pp. 20-29.

Nazarova, L., Chironomids in Quaternary permafrost deposits in the Siberian Arctic. Chironomus, Newsl. Chironomid Res., 2012, vol. 25, pp. 39-42.

Nazarova, L., de Hoog, V., Hoff, U., and Diekmann, B., Late Holocene climate and environmental changes in
Kamchatka inferred from subfossil chironomid record, Quat. Sci. Rev., 2013, vol. 67, pp. 81-92.

Nazarova, L.B., Frolova, L.A, Kosareva, L.R., Rudaya, N.A., Syrykh, L.S., Gafiatullina, L.I., Kuzina, D.M., Palagushkina, O.V., Tumanov, O.N., and Fefilova, E.B., Magnetic-mineralogical and biological indices of bottom sediments of the Bol'shoi Kharbei Lake, Zh. Sib. Fed. Univ., Biol., 2014, no. 7, pp. 372-394.

Nazarova, L., Herzschuh U., Wetterich, S., Kumke, T., and Pestrjakova, L., Chironomid-based inference models for estimating mean July air temperature and water depth from lakes in Yakutia, northeastern Russia, $J$. Paleolimnol., 2011, vol. 45, pp. 57-71.

Nazarova, L.B., Pestryakova, L.A. Ushnitskaya, L.A. and Hubberten, H.-W., Chironomids (Diptera: Chironomidae) in lakes of central Yakutia and their indicative potential for paleoclimatic research, Contemp. Probl. Ecol., 2008, vol. 1, no. 3, pp. 335-345.

Nazarova, L., Self, A., Brooks, S.J., van Hardenbroek, M., Herzschuh, U., and Diekmann, B., Northern Russian chironomid-based modern summer temperature data set and inference models, Global Planet. Change, 2015, vol. 134, pp. 10-25.

Nazarova, L.B., Semenov, V.F., Sabirov, R.M., and Efimov, I.Yu., The state of benthic communities and water quality evaluation in the Cheboksary Reservoir, Water Resour., 2004, vol. 31, no. 3, pp. 316-322.

New, M., Lister, D., Hulme, M., and Makin, I., A highresolution data set of surface climate over global land areas, Clim. Res., 2002, vol. 21, pp. 1-25.

Nikanorov, A.M., Gidrokhimiya (Hydrochemistry), St. Petersburg: Gidrometeoizdat, 2001.

Palagushkina, O.V., Nazarova, L.B., and Frolova, L.A., Diatoms from the Holocene deposits of the Bol'shoi Kharbei Lake (Bol'shezemel'skaya tundra, Russia), $Z h$. Sib. Fed. Univ., Biol., 2014, no. 7, pp. 395-410.

Palagushkina, O.V., Nazarova, L.B., Wetterich, S., and Shirrmaister, L., Diatoms from sediments of water bodies of Siberian Arctic, Contemp. Probl. Ecol., 2012, vol. 5, no. 4, pp. 413-422.

Pielou, E.C., The measurement of diversity in different types of biological collections, Theor. Biol. J., 1966, vol. 57 , no. 13 , pp. $131-144$.

R Development Core Team, R: A Language and Environment for Statistical Computing, Vienna: R Found. Stat., 2013.

Self, A.E., Brooks, S.J., Birks, H.J.B., et al., The distribution and abundance of chironomids in high-latitude Eurasian lakes with respect to temperature and continentality: development and application of new chironomid-based climate-inference models in northern Russia, Quat. Sci. Rev., 2011, vol. 30, pp. 1122-1141.

Shannon, C. and Weaver, W., The Mathematical Theory of Communication, Urbana, IL: Univ. Illinois Press, 1964.

Smol, J.P., Wolfe, A.P., Birks, H.J.B., Douglas, M.S.V., Jones, V.J., Korhola, A., Pienitz, R., Rühland, K., Sorvari, S., Antoniades, D., Brooks, S.J., Fallu, M.-A., Hughes, M., Keatley, B., Laing, T., et al., Climatedriven regime shifts in the biological communities of Arctic lakes, Proc. Natl. Acad. Sci. U.S.A., 2005, vol. 102, no. 12, pp. 4397-4402. 
Solovieva, N., Jones, V.J., Appleby, P.G., and Kondratenok, B.M., Extent, environmental impact and longterm trends in atmospheric contamination in the USA basin of East-European Russian Arctic, Water, Air Soil Pollut., 2002, no. 139, pp. 237-260.

Solovieva, N., Jones, V.J., Birks, H.J.B., Appleby, P.G., and Nazarova, L., Diatom responses to 20th century climate warming in lakes from the northern Urals, Russia, Palaeogeogr., Palaeoclimatol., Palaeoecol., 2008, vol. 259, pp. 96-106.

Solovieva, N., Jones, V.J., Nazarova, L., Stephen, J., Brooks, S.J., Birks, H.J.B., Grytnes, J.-A., Appleby, P.G., Kauppila, T., Kondratenok, B., Renbergm, I., and Ponomarev, V., Paleolimnological evidence for recent climatic change in lakes from the northern Urals, arctic Russia, J. Paleolimnol., 2005, vol. 33, pp. 463-482.

ter Braak, C.J.F., Non-linear methods for multivariate statistical calibration and their use in palaeoecology: a comparison of inverse $(k$-nearest neighbors, partial least squares and weighted averaging partial least squares) and classical approaches, Chemom. Intell. Lab. Syst., 1995, vol. 28, no. 1, pp. 165-180.

ter Braak, C.J.F. and Prentice, I.C., A theory of gradient analysis, Adv. Ecol. Res., 1988, vol. 64, no. 18, pp. 271317.

ter Braak, C.J.F. and Šmilauer, P., CANOCO Reference Manual and CanoDraw for Windows User's Guide: Software for Canonical Community Ordination (Version 4.5), Ithaca, NY: Microcomp. Power, 2002a.

ter Braak, C.J.F. and Šmilauer, P., CANOCO V. 4.5, Ithaca, NY: Microcomp. Power, $2002 b$.
Vlasova, T.A., Hydrological and hydrochemical conditions for biological production in the Kharbey Lake system, in Produktivnost' ozer vostochnoi chasti Bol'shezemel'skoi tundry (Productivity of the Lakes of the Eastern Part of Bol'shezemel'skaya Tundra), Leningrad: Nauka, 1976, pp. 6-26.

Vorkuta-gorod na ugle, gorod v Arktike (Vorkuta: The City of Coal in Arctic), Getsen, M.V., Eds., Syktyvkar, 2011.

Wiederholm, T., Chironomidae of the Holarctic Region: Keys and Diagnoses, Part 1: Larvae, Andersen, T., Cranston, P.S., and Epler, J.H., Eds., Lund: Scandinavian Entomology, 1983, no. 19.

Woodcock, T., Longcore, J., McAuley, D., Mingo, T., Bennatti, C.R., and Stromborg, K., The role of $\mathrm{pH}$ in structuring communities of main wetland macrophytes and chironomid larvae (Diptera), Wetlands, 2005, vol. 25 , pp. $306-316$.

Zinchenko, T.D., Ekologo-faunisticheskaya kharakteristika khironomid (Diptera, Chironomidae) malykh rek basseina Srednei $i$ Nizhnei Volgi (Atlas) (Ecological and Faunistic Characteristics of Chironomids (Diptera, Chironomidae) from the Small Rivers of Central and Lower Volga River Basin: Atlas), Tolyatti: Kassandra, 2011.

Zvereva, O.S., Vlasova, T.A., Goldina, L.P., and Izyurova, V.K., The results of limnological studies in the Bol'shezemel'skaya tundra, in Biologicheskie osnovy ispolzovania prirody Severa (Biological Principles of Use of the Northern Nature), Syktyvkar: Komi Knizhn. Izd., 1970, pp. 248-253. 